\title{
Let that posterior leaflet swing—but not too much!
}

\author{
W. Randolph Chitwood, Jr, MD, FACS, FRCS
}

\author{
From the Department of Cardiovascular Sciences, Brody School of Medicine, East Carolina University, Green- \\ ville, NC. \\ Disclosures: Author has nothing to disclose with regard to commercial support. \\ Received for publication June 7, 2017; accepted for publication June 12, 2017; available ahead of print July 26 , \\ 2017. \\ Address for reprints: W. Randolph Chitwood, Jr, MD, FACS, FRCS, 146 East Longmeadow Rd, Greenville, NC \\ 27858 (E-mail: chitwoodw@ecu.edu). \\ J Thorac Cardiovasc Surg 2017;154:1245-6 \\ $0022-5223 / \$ 36.00$ \\ Copyright (C) 2017 by The American Association for Thoracic Surgery \\ http://dx.doi.org/10.1016/j.jtcvs.2017.06.024
}

At first, Alain Carpentier repaired both degenerative and rheumatic valves. However, he found that repaired degenerative valves had the best long-term success. ${ }^{1}$ In 1986, I learned from "the professor" how to repair mitral valves. He taught us descriptive nomenclature, valve assessment, and repair techniques. The latter usually consisted of a large quadrangular resection of the posterior leaflet. The incision was carried to the annulus, leaving a large gap between remaining leaflet tissue. The annular defect was pulled together with big suture bites. Then, one or more anterior leaflet chords were shortened by burying the elongated chord in a papillary muscle "trench" or by performing a papillary folding-plasty. Finally, a rigid annuloplasty ring completed the operation. Most often the posterior leaflet never moved again. After cardiopulmonary bypass, the often professor took a sterile stethoscope and listened to the exposed heart- "Ah, no murmur!"

Repair techniques have evolved significantly, but basic repair principles remain: (1) correct the leaflet prolapse; (2) maintain adequate leaflet coaptation; (3) manage excess tissue; (4) support all leaflets; and (5) remodel the annulus. In the last 20 years, new repair techniques have proven to be quite successful. First, it was the addition of polytetrafluoroethylene (PTFE) neochords by Frater and David, as the trench-shortening method often failed. ${ }^{2}$ Mohr and the Leipzig group showed that, using PTFE loops, leaflet resection became unnecessary. ${ }^{3}$ Limited triangular leaflet resections and folding-plasties were proven to be successful. ${ }^{4}$ Dreyfus amputated the coapting end of a large $\mathrm{P}_{2}$ with native chord reimplantation." Our modified "haircut technique" supported $\mathrm{P}_{2}$ using chord bearing leaflet tissue "flaps" or PTFE neochords. ${ }^{6}$ Perier championed the respect rather than resect concept to maintain leaflet motion, and it has proliferated. ${ }^{7}$ Each of these positions has moved away from large leaflet resections and disruption of the annular-leaflet junction. The notion is to preserve posterior leaflet motion-Let that posterior leaflet swing, but not swing too much!

In the current article, Agnino and colleagues ${ }^{8}$ emphasize $^{-}$ the importance of maintaining natural leaflet motion or a swinging leaflet-annulus hinge after a mitral repair. The

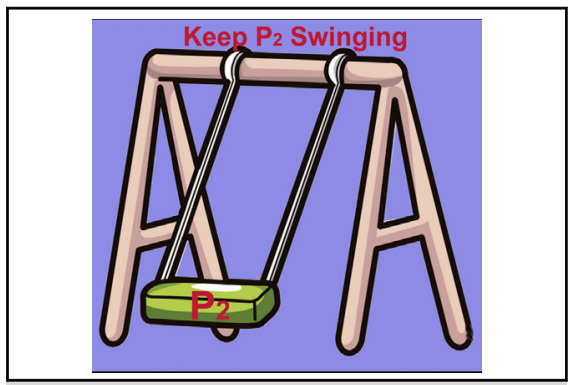

It is important to preserve posterior leaflet "swing" after a mitral repair.

\section{Central Message}

Most modern mitral repair techniques attempt to maintain natural posterior leaflet motion. Herein a novel repair method is described that should preserve this motion and decrease the risk of anterior leaflet systolic anterior motion.

See Article page 1247.

authors show a novel method that should preserve this motion while maintaining the basic posterior leaflet repair principles. This nonresectional technique seems to be appropriate in the presence of a large $\mathrm{P}_{2}$ flail or prolapse. $\mathrm{F}$ leaflet support the repair relies completely on adjacent normal chords of $\mathrm{P}_{1}$ and $\mathrm{P}_{2}$. Although long-term results are absent, this method seems reasonable because it reduces both the prolapse and the height of $\mathrm{P}_{2}$ simultaneously while garnering chordal support from adjacent normal tissue and maintaining leaflet mobility. A Barlow's type of posterior leaflet with a very large $\mathrm{P}_{1}$ and $\mathrm{P}_{3}$ would probably contraindicate using this technique. The authors believe that this technique should save cardiac arrest time in comparison with other techniques: however, the average times posted in this paper are similar to some sternotomy-based series. It is time that we stop "stylizing" or calling repair techniques just for minimally invasive approaches, as many have the same results as operations done through a sternotomy.

\section{References}

1. Braunberger E, Deloache A, Berribi A, Abdallah F, Celestin JA, Meimon P, et al. Very long-term results (more than 20 years) of valve repair with Carpentier's techniques in non-rheumatic mitral valve insufficiency. Circulation. 2001;104(12 suppl 1):8-11.

2. David TE, Armstrong S, Ivanov J. Chordal replacement with polytetrafluoroethylene sutures for mitral valve repair: a 25-year experience. J Thorac Cardiovasc Surg. 2013;145:1563-9.

3. Seeburger J, Falk V, Borger M, Passage J, Walther T, Doll N, et al. Chordae replacement versus resection for repair of isolated posterior mitral leaflet prolapse: à ègalité. Ann Thorac Surg. 2009;87:1715-20.

4. Schwartz CF, Grossi EA, Ribakove GH, Ursomanno P, Mirabella M, Crooke GA et al. Ten-year results of folding plasty in mitral valve repair. Ann Thorac Surg. 2010;89:485-9. 
5. Dreyfus GD, Corbi S, Rubin S, Aubert S. Posterior leaflet preservation in mitral valve prolapse: a new approach to mitral valve repair. J Heart Valve Dis. 2006; 15:528-30.

6. Chitwood WR. Haircut mitral valve repair: posterior leaflet-plasty. Ann Cardiothorac Surg. 2015;4:387-92.
7. Perier P. A new paradigm for the repair of posterior leaflet prolapse: respect rather than resect. Op Tech Thorac Cardiovasc Surg. 2005;10:180-93.

8. Agnino A, Parrinello M, Panisi P, Anselmi A. Novel nonresectional posterior leaflet remodeling approach for minimally invasive mitral repair. J Thorac Cardiovasc Surg. 2017;154:1247-9. 